\title{
Comparison of the effectiveness of four group therapies in improving the quality of life in menopausal women
}

\section{Porównanie skuteczności czterech modeli terapii grupowej w poprawie jakości życia kobiet w okresie menopauzalnym}

\author{
Forugh Jafary ${ }^{1}$, Leila Afzali² \\ 1Department of Counseling, Islamshahr Branch, Islamic Azad University, Islamshahr, Iran \\ 2University of Tehran, Iran
}

Przegląd Menopauzalny 2013; 3: 194-201

\section{Summary}

The aim of the study was to compare the effectiveness of group therapy based on meaning in life, self-efficacy, body image or the combination of the three factors in improving the quality of life in menopausal women.

Material and methods: The research sample consisted of 54 menopausal women (45-55 years) selected from women's associations at cultural centers in Tehran. There were four experimental groups (group therapy based on meaning in life, self-efficacy, body image and a combination of the three factors) and a control group. A quality of life questionnaire (sf-36) was used as a pre-test, post-test and follow-up test (3 months after group therapy) measure in each of the five groups. The group therapy sessions for the experimental groups were held 12 times (for 3 months). Statistical analysis was performed using variance analysis tests, Schefe follow-up tests and covariance analysis.

Results: Results of covariance analysis showed a significant increase in quality of life as a result of group therapy based on meaning in life $(p<0.05)$, group therapy based on self-efficacy $(p<0.05)$ and group therapy based on the combination of three factors $(p<0.01)$. Group therapy based on body image alone resulted in no significant changes in quality of life. Follow-up test results after the three-month period showed continuity of the results.

Conclusions: Group therapy based on a combination of meaning in life, self-efficacy and body image offers a higher and more durable increase in quality of life.

Key words: women, quality of life, meaning in life, self-efficacy beliefs, body image.

\section{Streszczenie}

Cel pracy: Celem badania było porównanie skuteczności terapii grupowej opartej na sensie życia, samoocenie, wyobrażeniu własnego ciała lub kombinacji tych trzech czynników w poprawie jakości życia kobiet w wieku menopauzalnym.

Materiał i metody: Badana grupa objęła 54 menopauzalnych kobiet (45-55 lat) wybranych z różnych centrów kulturowych Teheranu. Wyodrębniono 4 eksperymentalne grupy (z terapią oparta na sensie życia, samoocenie, wyobrażeniu własnego ciała i kombinacji tych 3 czynników) oraz grupę kontrolną. Zastosowano quality of life questionnaire (sf-36) przed badaniem, w jego trakcie i jako follow-up (3 miesiące po terapii grupowej) w każdej z pięciu grup. Sesje terapii grupowej odbywały się 12 razy (przez 3 miesiące). Do analizy statystycznej użyto testu analizy wariancji, testu follow-up Schefe'a i analizie kowariancji.

Wyniki: Wyniki analizy kowariancji wykazały istotną poprawę jakości życia jako wynik terapii grupowej opartej na sensie życia $(p<0,05)$, terapii grupowej opartej na samoocenie $(p<0,05)$ i opartej na kombinacji trzech czynników $(p<0,01)$. Terapia grupowa oparta tylko na wyobrażeniu własnego ciała nie skutkowała zmianami w jakości życia. Wyniki kontrolnych testów po 3 miesiącach wykazały utrzymanie się poprawy jakości życia

Wnioski: Terapia grupowa oparta na kombinacji sensu życia, samooceny i wyobrażeniu własnego ciała skutkuje wyraźniejszą i bardziej długotrwałą poprawą jakości życia.

Słowa kluczowe: kobiety, jakość życia, sens życia, samoocena, wyobrażenie własnego ciała. 


\section{Introduction}

In the past century, the average life expectancy for women in all geographic areas around the world increased from 48.3 years in 1900 to 79.8 years in 2001 [1]. Therefore, many more women are living longer after having reached the age of menopause.

Menopause is essentially the last stage of the ovarian function, leading to full incapacitation of the ovaries to produce hormones. Menopause can lower the quality of life through changes in hormone production, moods, health and physical conditions [2].

One may say that quality of life consists of subjective and objective indexes. Subjective indexes would include, for example, satisfaction or feeling of pleasure as a result of an individual evaluating her life. Objective indexes would include environmental conditions that affect quality of life [3]. Individual self-reflection, including attitude towards life, medical treatment and other perspectives, have great effects on the quality of life [4].

Menopausal changes appear at an age when the former fundamental life may have been put at risk. Women who are approaching the age of 50 have usually already been confronted with stressful experiences, such as helping their children through puberty or experiencing their children leaving home, need to care for elderly parents, retirement (their own or spouse's) and possibly decreases in employment challenges and work satisfaction. Perhaps, separating these issues from specific factors involved in menopause would be beneficial [5].

When analyzing meaning in life it should be considered that life is more meaningful for people when they have a model or goal for their life events. Meaning in life is based on a context that acts as a platform, giving a person's life form and direction in connection with life objectives and values. Individual perceptions of personal life factors play a great role when assessing the quality of life [6].

Life becomes meaningful for people only when they can maintain a role or keep a goal in mind in their life events. Studies have shown that people with higher life-goal scores (i.e., greater meaning in life) have more self-acceptance [7], greater life satisfaction [8], bear greater responsibilities and have more self control [9]. It seems that having meaning in life is one of the effective factors in quality of life.

Menopause is a time when a woman pauses and reviews her beliefs in herself and the surrounding world. Perhaps, a woman might take steps in a direction she was always interested in but was not able to envisage [10]. Women may experience achievement of special goals or sometimes loss of a goal. As a result, there may be ambiguity and changes in meaning in life. Analyzing meaning in life is, therefore, important in menopausal women.
Self-efficacy is attributed to the feeling of value, selfesteem, feeling of sufficiency and efficacy in handling events of life [11]. Several studies have shown that selfefficacy has a relationship with the general feeling of well-being; that is, quality of life [12].

Greater perception of one's abilities drives people to make an effort at meeting challenges. On the other hand, low self-efficacy weakens motivation and increases a sense of low sufficiency [12]. Therefore, it could be said that if self-evaluation of menopausal women results in an assessment of less cognitive power, physical strength and physical attraction, then important goal setting (as the most essential index of meaning) would be reduced accordingly. Self-efficacy in menopausal women is an important factor to consider in analyzing quality of life.

The body image as the meaning of emotions, attitudes and values of an individual concerning her body and function [13]. Body image is the most important characteristic that undergoes judgment when individuals meet each other [14].

There have been few studies on body image in post-menopausal conditions, however, some studies have shown that psychological and physiological changes following menopause create concerns about weight and diet. Changes in weight distribution occur during menopause that lead to a rounder bodily shape, larger breasts and waist size and fat accumulation in the upper back of the body [15]. In addition, women at a premenopausal age have been shown to assign more positive scores to a physical evaluation and proportional measurement than menopausal women [16]. Studies on the potentially destructive effects of this phenomenon showed that a poor physical image leaves negative effects on psychological compatibility [17], as well as an increased risk of depression [18] and mental and physical health conditions [19]. Body image in menopausal women is an important consideration in assessing quality of life.

Compared to advanced countries, very few studies on the quality of life at a menopausal age have been carried out in developing countries in Asia. Asian countries differ politically, economically and socially, as well as in their elderly care systems and, therefore, studies performed in Asian countries have provided heterogenic results [20]. Also, considering the fact that psychological treatments move towards multidimensional viewpoints, a regional study of factors playing a role in quality of life is warranted.

Schneider, Maclennan and Feeny [21] suggested that menopause and its relevant issues affect women's health and can affect quality of life. Steger et al. [22] showed that meaning in life plays an important role in well-being throughout an individual's entire life. Skrabski et al. [23] showed that although meaning in life has a positive correlation with self-efficacy, the importance 
of religion, ability in confronting problems and using social supports are also important. Pesa, Syre and Jones [24] found that overweight women have a poor physical self-image and suffer from low self-confidence. Low and Molzahn [25] used path analysis to show that financial resources affect health and meaning in life positively and directly and health, passionate supports and physical environment, indirectly and through goals in life affect the quality of life. These studies provide direction in considering the relevant issues for quality of life in menopausal women.

Although various studies have aimed at analyzing one or two of the aforementioned indexes in menopausal women, no study analyzed group therapy sessions based on meaning in life, self-efficacy and body image. In the present study four experimental groups underwent group therapy based on three indexes: meaning in life (taken from a meaning therapy approach), self-efficacy (taken from Bandura's cognitive-social approach) and body image (taken from socio-cultural theory) and a combination of them in order to study the effectiveness of group therapy methods in improving the quality of life of menopausal women.

\section{Material and methods}

\section{Selecting the participants}

The sample group was formed by selecting women who were participants in scientific, recreational, sports and social activities in cultural centers in Tehran. The research was carried out from July 2010 through December 2010. The selected individuals had at least a high school diploma and were in the age range of 45 years to 55 years with experiences of menopausal signs (a disorder or permanent pause in monthly menstruation). They were all married women with no diseases that would have caused disorders in menopause. The women were chosen from six cultural centers in different geographic and cultural areas of Tehran City. Sixty women (10 women from each cultural center) were selected and, after participating in a briefing session on the research plan and giving their written consent, were assigned to one of five groups (four experimental groups and a control group) at random. Each individual took a pre-test in a group session (quality of life test sf-36). The experimental groups then participated in 12 group therapy sessions (one 1.5-hour session per week for 3 months) and all members of the five groups completed a post test (quality of life test sf-36) after completing the sessions. In the first five sessions, five participants withdrew from regular attendance and were thus omitted from the research study. One of the members of the control group did not participate in the post-test stage and, therefore, the total final number of participants was 54 .

\section{Contents of group therapy sessions}

At the beginning of the series of sessions for each of the four experimental groups, an introduction was made, the rules of the group were described and the quality of life sf-36 pre-test was administered. Each subsequent therapy session started by discussing the assignments from the previous week and ended by agreeing on new assignments. In the initial session, there was a discussion in all groups on the importance of menopause and its effects on different physical, psychological and social dimensions.

\section{Group therapy based on meaning in life}

The definition of meaning in life, its dimensions and importance and the necessity of having a perception of meaning in life were discussed in the group therapy sessions based on meaning in life. Finding goals in life, characteristics of suitable goal setting, feelings of value, methods of giving meaning in life and finding meaningful activities in one's present life, finding the characteristics of a valuable life, talking about perceptions of death, limitations of life and the role of awareness in creating meaning were discussed. Views were exchanged on knowing the underlying life story of each member, seeking goals and envisaging unfinished works, determining the triple methods for giving meaning to life events (work, love, suffering) and directing members towards seeking valuable meaning in their personal life. The importance of establishing new meaning with respect to changes emerging from menopause, correction of stereotypes and wrong beliefs about menopause were topics included in the therapy sessions of this group.

\section{Group therapy based on self-efficacy}

Group therapy based on self-efficacy included an introduction to the cognitive school of thought and self-efficacy beliefs. The role of beliefs and ideas in an individual's life functions, discussion on different types of self-efficacy beliefs, definition of a self-statement, the role of emotions in self-statements, the role of the individuals themselves in self-statements and the effects of self-statements on self-efficacy were discussed in these group therapy sessions. Practicing methods were introduced to know the relationship and effects of self-statements on the beliefs and emotions of individuals as well as identification of effective factors in the formation of self-efficacy. The relationship of age and self-efficacy and the effect of menopause on self-efficacy were included with the intent of seeking common goals that would fit menopausal conditions.

\section{Group therapy based on body image}

Group therapy based on body image included explanations of body image and its importance in women's lives. Changes that take place after menopause were discussed in this group. Expressing 
views on one's own body and checking it with an ideal, the role of irrational beliefs and cognitive biases on body image, the importance of self-statements in changing body image, exercising positive daily selfstatements in connection with the body and registering the emotions therefore, correcting the thoughts on the value of the body in success, life satisfaction and gender viewpoints of women, and determining the share of effective factors other than body image on self-satisfaction were important in group therapy sessions in this group.

\section{Group therapy based on the combination}

of meaning in life, self-efficacy and body image

Explanations and descriptions of meaning in life, self-efficacy and body image, with emphasis on the relationship between them, as well as changes during menopause were offered in the group therapy based on the combined factors. The effects of selfstatements and positive thoughts in changing the three factors and the role each plays during changes in life satisfaction were considered. Exercises were provided to find meaning in life as well as goals and values in life in accordance with the new conditions of menopause. Promotion of self-efficacy by recognizing successful past experiences, considering models of similar successful individuals or seeking past social confirmations were included in the sessions. Coping with physical and body changes, accepting them, and dealing with exaggeration and excessive aggrandizement or feelings of happiness and life satisfaction due to physical attractiveness were analyzed in the group therapy sessions.

\section{Research tools}

Questionnaire for quality of life assessment (sf-36): The sf-36 is a 36-item questionnaire for measuring quality of life. Montazeri et al. [26] translated the questionnaire and performed the necessary pscychometric studies to prepare this assessment tool to be used in Iran. The Cronbach's $\alpha$, as reported for the eight dimensions of this tool, is in $65-90 \%$ range. The scale in this questionnaire includes eight dimensions of physical function, physical functioning, role limitation due to physical health, bodily pain, general health, vitality, social functioning, role limitation due to emotional problems and mental health.

\section{Statistical analysis}

The data were analyzed using SPSS 17 software. Descriptive statistical methods, analysis of variance (ANOVA; for determining the differences in mean average scores of groups) and covariance analysis (ANCOVA; for determining the effectiveness of group therapy in each of the groups) were carried out and the differences between pre-test and post-test scores as well as differences between experimental groups and the control group were studied.

\section{Results}

Table I shows the mean scores and criteria deviations for pre-tests and post-tests, as well as the follow-up tests (three months after post-tests), for the four experimental and control groups. In the deductive statistics analysis, due to establishing the hypothesis of variance analogy and the existence of linear combination as one of the pre-assumptions in ANCOVA tests, covariance analysis was adopted for the six research hypotheses order to analyze the data and determine significance. The hypotheses in this research is whether group therapy based on meaning in life could be effective in improving quality of life of menopausal women, whether group therapy based on self-efficacy could be effective in improving quality of life of menopausal women, whether group therapy based on body image could be effective in improving quality of life of menopausal women, whether group therapy based on a combination of meaning in life, selfefficacy and body image could be effective in improving the quality of life of menopausal women, whether the results of scores given to the quality of life of the four experimental groups reveal significant differences and whether the three-month follow-up tests would confirm the previous results and could prove that the changes which emerged were not temporary.

The results of covariance analysis for group sessions based on meaning in life, self-efficacy, body image and their combination are listed in Table II.

Results for the first question (whether group therapy based on meaning in life could be effective in improving quality of life of menopausal women), shown in Table II, indicated that the pre-test effect was significant $(F=202 / 62, p<0.001)$ and the effect of the independent variable was statistically more significant by omitting the balancing variable $(F=7 / 90, p<0.05)$. This suggests that group therapy based on meaning in life resulted in improvement in quality of life in this experimental group.

Results for the second question (whether group therapy based on self-efficacy could be effective in improving quality of life of menopausal women), shown in Table II, indicated that the pre-test effect was significant $(F=139 / 74, p<0.001)$ and the effect of the independent variable was statistically more significant by omitting the balancing variable $(F=6 / 82$, $p<0.05)$. This suggests that group therapy based on self-efficacy resulted in improvement in quality of life in this experimental group.

Results for the third question (whether group therapy based on body image could be effective in improving quality of life of menopausal women), 
Tab. I. Mean scores and criteria deviations for pre-test and post-test scores and follow-up tests for the four experimental groups and the control group

\begin{tabular}{llcccccc}
\hline & \multirow{2}{*}{} & \multicolumn{2}{c}{ Pre-test } & \multicolumn{2}{c}{ Post-test } & \multicolumn{2}{c}{ Follow-up test } \\
\cline { 2 - 8 } & & mean & SD & mean & SD & mean & SD \\
\hline Meaning in life & 11 & 26.45 & 7.58 & 29.45 & 6.875 & 29.27 & 6.03 \\
\hline Self-efficacy & 11 & 28.45 & 7.55 & 31.45 & 6.37 & 32.18 & 4.89 \\
\hline Body image & 12 & 29.50 & 8.09 & 30.66 & 6.06 & 30.58 & 5.82 \\
\hline Combination & 10 & 29.10 & 7.26 & 37.20 & 4.51 & 35.80 & 4.07 \\
\hline Control & 10 & 29.40 & 6.86 & 29.60 & 7.16 & 29.70 & 5.81 \\
\hline
\end{tabular}

Tab. II. Summary of covariance analysis on quality of life scores (post-test) per group

\begin{tabular}{|c|c|c|c|c|c|c|}
\hline Group therapy based on & Resource & Sum of squares & df & Mean squares & $\mathrm{F}$ & Sig. \\
\hline \multirow[t]{4}{*}{ meaning in life } & independent variable & 858.832 & 1 & 858.832 & 202.620 & 0.000 \\
\hline & group & 33.489 & 1 & 33.489 & 7.901 & 0.012 \\
\hline & error & 76.296 & 18 & 4.239 & & \\
\hline & total & 19240 & 21 & & & \\
\hline \multirow[t]{4}{*}{ self-efficacy } & independent variable & 769.950 & 1 & 769.950 & 139.740 & 0.000 \\
\hline & group & 37.619 & 1 & 37.619 & 6.828 & 0.018 \\
\hline & error & 99.178 & 18 & 5.510 & & \\
\hline & total & 20514 & 21 & & & \\
\hline \multirow[t]{4}{*}{ body image } & independent variable & 790.591 & 1 & 790.591 & 196.417 & 0.000 \\
\hline & group & 5.277 & 1 & 5.277 & 1.311 & 0.266 \\
\hline & error & 76.476 & 19 & 4.025 & & \\
\hline & total & 20914 & 22 & & & \\
\hline \multirow{4}{*}{$\begin{array}{l}\text { meaning in life, self-efficacy } \\
\text { and body image }\end{array}$} & independent variable & 539.278 & 1 & 539.278 & 85.903 & 0.000 \\
\hline & group & 306.572 & 1 & 306.572 & 48.835 & 0.000 \\
\hline & error & 106.722 & 17 & 6.278 & & \\
\hline & total & 23246 & 20 & & & \\
\hline
\end{tabular}

shown in Table II, indicated that the pre-test effect was significant $(F=196 / 41, p<0.001)$; however, the effect of the independent variable was not statistically significant by omitting the balancing variable $(F=1 / 31$, $p<0.05)$. This suggests that group therapy based on body image did not result in improvement in quality of life in this experimental group.

Results for the fourth question (whether group therapy based on combination of meaning in life, selfefficacy and body image could be effective in improving the quality of life of menopausal women), shown in Table II, indicated that the pre-test effect was significant $(\mathrm{F}=85 / 90, p<0.001)$ and the effect of the independent variable was statistically more significant by omitting the balancing variable $(F=48 / 83, p<0.001)$. This suggests that group therapy based on combination of meaning in life, self-efficacy beliefs and body image resulted in improvement in quality of life in this experimental group.

Table III lists results for question five (whether the results of scores given to the quality of life in the four experimental groups reveal significant differences). The results of a one-sided ANOVA on quality of life scores per therapy group in menopausal women showed that there were significant differences between scores of the experimental groups $(F=2 / 63$, $p<0.05)$. The results of follow-up Shefe tests also showed that there were significant differences between the mean scores for the group that underwent therapy based on meaning in life, self-efficacy beliefs and body image compared to the scores of other groups $(\mathrm{t}=2.95$, $p<0.01)$.

Table IV shows the quality of life follow-up scores for the therapy group based on meaning in life. The effects of the pre-test were statistically significant $(F=163 / 38$, $p<0.001$ ) and the effect of the independent variable was statistically significant by omitting the balancing variable $(F=7 / 90, p<0.05)$. This result suggests the effectiveness of the sessions continued for three months. In addition, the results of group therapy based on self-efficacy showed that the effects of the pre-test was statistically significant $(F=52 / 83, p<0.001)$ and the effect of the independent variable was statistically significant by omitting the balancing variable $(F=6 / 46$, 
$p<0.05)$. Here it could also be said that the sessions continued for three months were effective. The results of group therapy based on body image were not significant in post-tests. In addition, the group therapy results based on the combination of meaning in life, self-efficacy beliefs and body image showed that the pre-test effect was statistically significant $(F=$ $125 / 33, p<0.001$ ) and the effect of the independent variable was statistically significant by omitting the balancing variable $(F=62 / 22, p<0.001)$. It could be said that these sessions continued for three months were effective.

\section{Discussion and conclusions}

The results of our study show that the group therapy sessions based on meaning in life, self-efficacy and the combination of meaning in life, self-efficacy and body image improved the quality of life in menopausal women. The group therapy sessions based on body image showed no significant increases in post-test and follow-up quality of life scores.

In determining improvement in quality of life with emphasis on meaning in life, results showed that the existence of meaning has a close relationship with inner well-being. Seeking meaning has been associated with drastic changes in well-being at the old age [22]. Other characteristics of meaning that relate to quality of life are the feeling of worth, inner peace, positive emotions, and feelings and thoughts of satisfaction. Therefore, by working towards creating motivation and valuable personal goals during menopause, individuals could use knowledge and application of the three ways of seeking meaning (work, love, suffering), to find motivation and reasons for activities. Westgate (1996) concluded that finding meaning in life via creative values, spirituality and attachment to other people and subjects could be very effective in treating depression [27]. Debats, Drost and Hanson [28] reported feelings of meaningfulness in connection with variables such as general satisfaction in life, happiness, self-confidence, positive views towards others and positive attitudes towards life and they found a connection between lack of meaning in life and the lack of social identity, social isolation and vulnerability. Chamberlain and Zika [29] showed a significant relationship between finding meaning in life and satisfaction in life.

Based on our results, sessions that focused on selfefficacy improved the quality of life. Previous studies have shown that self-efficacy relates to feelings of

Tab. III. Results of an ANOVA analysis on quality of life scores per therapy group in menopausal women

\begin{tabular}{lccccc}
\hline & Sum of squares & df & Mean squares & F & Sig. \\
\hline Between Groups & 414.916 & 4 & 103.729 & 2.633 & \\
\hline Within Groups & 1930.121 & 49 & 39.390 & \\
\hline Total & 2345.037 & 53 & & \\
\hline
\end{tabular}

Tab. IV. Summary of results from an ANOVA analysis on quality of life scores (follow-up tests) per group

\begin{tabular}{|c|c|c|c|c|c|c|}
\hline $\begin{array}{l}\text { Group therapy } \\
\text { based on }\end{array}$ & Resource & Sum of squares & df & Mean squares & $\mathrm{F}$ & Sig. \\
\hline \multirow[t]{4}{*}{ meaning in life } & independent variable & 651.26 & 1 & 651.26 & 163.38 & 0.000 \\
\hline & group & 33.53 & 1 & 33.53 & 8.41 & 0.01 \\
\hline & error & 71.74 & 18 & 3.98 & & \\
\hline & total & 19384 & 21 & & & \\
\hline \multirow[t]{4}{*}{ self-efficacy } & independent variable & 405.57 & 1 & 405.57 & 52.83 & 0.000 \\
\hline & group & 49.63 & 1 & 49.63 & 6.46 & 0.02 \\
\hline & error & 138.16 & 18 & 7.67 & & \\
\hline & total & 20757 & 21 & & & \\
\hline \multirow[t]{4}{*}{ body image } & independent variable & 572.38 & 1 & 572.38 & 103.94 & 0.000 \\
\hline & group & 3.60 & 1 & 3.60 & 0.65 & 0.42 \\
\hline & error & 104.62 & 19 & 5.50 & & \\
\hline & total & 20722 & 22 & & & \\
\hline \multirow{4}{*}{$\begin{array}{l}\text { meaning in life, } \\
\text { self-efficacy } \\
\text { and body image }\end{array}$} & independent variable & 399.51 & 1 & 399.51 & 125.33 & 0.000 \\
\hline & group & 198.34 & 1 & 198.34 & 62.22 & 0.000 \\
\hline & error & 54.18 & 17 & 3.18 & & \\
\hline & total & 22091 & 20 & & & \\
\hline
\end{tabular}


general well-being $[12,30]$ and an individual's feeling of well-being is one of the most important dimensions of quality of life. On the other hand, women with higher selfefficacy levels set realistic goals that fit their abilities and, through effort and working toward goals, they benefit from a higher quality of life. The results of Levasseur and Tribble's research [6] show that personal factors such as health, inner life and behavioral abilities are important in quality of life. Joseph [31] found that there is an important significant relationship between self-efficacy beliefs and goals in life. These studies showed a positive relation between goals in life and multidimensional factors of well-being (including success, spirituality, balance and pleasure). Individuals who have high goals in life show other factors of psychological health as well. Esmaili [32] showed a significant relationship between quality of life and self-efficacy.

Based on our results, sessions that focused on body image had no effect on increasing the quality of life. Since the subjects had already been successful in job, social and family (marriage) terms, they probably had not been put in a position where their physical shape would play a determining role in being accepted or rejected. On the other hand, due to cultural conditions of the Iranian society, women at a menopausal age do not seem to have the intention of comparing themselves with the standards and ideals of society. Low sensitivity towards physical dimensions originates from disagreement with the roles defined for Iranian women; i.e., wife and mother in tradition and religion. Along these lines, Rutel [33] showed that older women paid significantly less attention to their physical shape (fitness, physical attraction and muscularity) than younger women. Anderson et al. [34] showed that, with age, more satisfaction regarding body size is observed. Clark (2002) showed that health evaluation scales and health direction in older people were much more important than physical image.

Based on our results, group therapy sessions that focused on meaning in life, self-efficacy and body image increased quality of life. Meaning in life had a close relationship with self-efficacy and women who were more goal-oriented and assessed themselves as worthy felt greater capability of achieving their goals. Meaning, in this case, gave them the necessary motives in their efforts per their abilities. Bandura [35] suggested that in societies that emphasize the potential of power for self-expansion in life, instead of feeling the loss of psychological-physical abilities, the elderly are more inclined to establish goals and productivity for themselves. The output of this process has an effect on quality of life and, in particular, having goals and positive expectations for the future. With respect to the contents presented in the group therapy sessions, when women accept their physical and mood changes, with emphasis on self-efficacy and meaning in life, they find more positive evaluation of their status and capability to make changes. They are able to set new goals that fit their present conditions and existing capabilities and develop a feeling of value. Consequently, they experience a better quality of life. Dibaian and Karami [36] showed a significant relationship between pleasure and finding meaning. In addition, indexes of life satisfaction, positive mood, health and self-confidence showed a significant relationship with seeking meaning. Lee and Oh [37] concluded that attention given to mental and psychological issues plays an important role in improving quality of life scores.

Including only menopausal women with a minimum of a high school diploma and selecting only women who live in Tehran were limitations of this research. In addition, similar sessions for non-menopausal women should be held and men of a similar age to menopausal women should be studied and the results should be compared to results for menopausal women. Group sessions based on other psychological indexes for quality life are other suggestions for future research endeavors.

\section{References}

1. Chen Y, Lin SQ, Wei Y, et al. Menopause-specific quality of life satisfaction in community-dwelling menopausal women in China. Gynecol Endocrinol 2007; 23: 166-72.

2. Chiu YW, Moore RW, Hsu CE, et al. Factors influencing women's quality of life in the later half of life. Climacteric 2008; 11: 201-11.

3. Afzalan Fatemeh. Evaluating quality of life in families of psychic patients. Social work M.Sc. Thesis, 2002.

4. Hartshorn JC, Byers VL. Impact of epilepsy on quality of life. J Neurosci Nurs. 1992; 24: 24-9.

5. Short M. Menopause, mood and management. Climacteric 2003; 6: 33-6.

6. Levasseur M, St-Cyr Tribble D, Desrosiers J. Meaning of quality of life for older adults: importance of human functioning components. Arch Gerontol Geriatr 2009; 40: e91-100.

7. Crumbaugh JC, Maholick LT. Manual of instructions for the purpose-inlife test. Munster, Psychometric Affiliates 1969.

8. Reker GT, Cousin JB. Factor structure, construct validity and reliability of the seeking of noetic goals (song) and purpose of life (PIL) tests. J Clin Psychol 1979; 35: 85-91.

9. Simmon DD. Purpose in life and the three aspects of valuing. J Clin Psychol 1980; 36: 921-2.

10. King DE, Hunter MH, Harris JR. Dealing with the Psychological and Spiritual Aspects of Menopause: Finding Hope in the Mid-Life. Haworth Pastoral Press, Birmingham 2005.

11. Bandura A. Self-efficacy mechanisms in human agency. Am Psychologist 1982; 37: 122-47.

12. Bandura A, Wood R. Effect of perceived controllability and performance standards on self-regulation of complex decision making. J Pers Soc Psychol 1989; 56: 805-14

13. Hubley AM, Quinlan L. Body image in men and women across the adult life span. VIII European Congress of Psychology in Vienna, Austria, July, 2003, 6-11.

14. Delamater JL. A study to determine the effect of the media on the perception of adolescent female body image and resultant relationship to academic achievement. Requirement for the Master of Science degree. University of Wisconsin, stout, 2002

15. Aminikhou M. Evaluating and university of welfare sciences \& rehabilitation, comparing the efficiency of narrative therapy, cognitive-behavioral treatment in body image and self-esteem in women with breast cancer. Psychology M.Sc. Thesis, Allameh Tabatabaee University, 2008.

16. Deek SA, McCabe MP. Menopausal stage and age and perception of body image. Psychology Health 2001; 16: 367-79. 
17. Cash TF, Winstead BA, Janda LH. Your body, yourself: A psychology today reader survey. Psychology Today 1985; 19: 22-6.

18. Noles SW, Cash TF, Winstead BA. Body image, physical attractiveness, and depression. J Consult Clin Psychol 1985; 53: 88-94.

19. Hurd LC. Older women's body image and embodied experiences: an exploration. J Women Aging 2000; 12: 77-97.

20. Ponyahotra S, Dennerstein L. Lehert P. Menopausal experiences of Tha women. Part 1: symptoms and their correlates. Maturitas 1997; 26: 1-7.

21. Schneider HP, Maclennan AH, Feeny D. Assessment health-related quality of life in menopause and aging. Climacteric 2008; 11: 93-107.

22. Steger MF, Oishi SH, Kashdan TB. Meaning in life across that life span: levels and correlates of meaning in life from emerging adulthood to older adulthood. J Positive Psychol 2009; 4: 43-52.

23. Skrabski A, Kopp M, Rózsa S, et al. Life meaning: an important correlate of health in the Hungarian population. Int J Behav Med 2005; 12: 78-85.

24. Pesa J, Syre T, Jones E. Psychosocial differences associated with body weight among female adolescents. J Adolesc Health 2000; 26: 330-7.

25. Low G, Molzahn AE. Predictors of quality of life in old age: a cross-validation study. Res Nurs Health 2007; 30: 141-50.

26. Montazeri A, Goshtasbi A, Vahdani M. Translation, validity and reliability Iranian Version of sf-36 Questioner. Quarterly J Payesh 2004; 49-50.

27. Corey G. Theory and Practice of Counseling and Psychotherapy. Thomson Brooks/Cole, California 1996.

28. Debats DL, Drost J, Hansen P Experiences of meaning in life: A combined qualitative and quantitative approach. Br J Psychol 1995; 86 (Pt 3): 359-375.

29. Chamberlain K, Zika S. Measuring meaning in life; an examination of three scales. Personality and Individual Differences 1988: 9: 589-96.
30. Bandura A, Cerrone D. Differential engagement of self-reactive influences in cognitive motivation. Organizational Behavior and Human Decision Processes 1986; 38: 92-113.

31. Joseph DS. Exploring the relationship between self-efficacy beliefs and purpose in life. PhD dissertation Ohio State University, 2004.

32. Esmaili M. Evaluating the relationship between quality of life and selfefficacy in hemodialysis patients in selected university hospitals of Iran University of Medical Sciences. Nursing M.Sc. Thesis, Iran University of Medical Sciences, 2005

33. Rutel EHA. Sociocultural context of body dissatis faction and possibilities of vibroacoustic therapy in diminishing body dissatisfaction. Dissertation on social sciences. Tallinn Pedagogical University, 2004.

34. Anderson LA, Eyler AA, Galuska DA, et al. Relationship of satisfaction with body size and trying to lose weight in a national survey of overweight and obese women aged 40 and older, United States. Prev Med 2002; 35: 390-6.

35. Bandura A. Health promotion from the perspective of social cognitive theory. J Psychol Health 1997; 13: 623-49.

36. Dibaian S, Karami A. Evaluating the relationship between search for meaning and welfare. National Seminar on Recreation and Happiness. University of Isfahan in cooperation with Isfahan municipality, Isfahan, 2006.

37. Lee JS, Oh WO. Factors influencing vitality among nurses. Taehan Kanho Hakhoe Chi 2007; 37: 676-83. 